удК 343

DOI https://doi.org/10.32837/apdp.v0i90.3208

О. Л. Іванова

\title{
ІСТОРИЧНИЙ АСПЕКТ ВИНИКНЕННЯ ТА РОЗВИТКУ ВІДПОВІДАЛЬНОСТІ ЗА СТАТЕВІ ЗЛОЧИНИ ЩОДО НЕПОВНОЛІТНІХ ОСІБ
}

Постановка проблеми. Сьогодні є гостра проблема в діяльності кожної держави щодо побудови та забезпечення дієвого механізму, який був би спрямований на функціонування належного захисту прав і свобод неповнолітніх осіб у різних сферах їхнього життя.

Тому цей захист здійснюється в межах державної політики, яка є по собі складовою частиною соціальної політики держави. Важливим елементом, який може бути спрямований на захист наймолодших членів суспільства, $є$ кримінально правовий захист. Але сексуальна революція, яка відбулася ще в $90-\mathbf{x}$ роках, а слідом за нею і безладне сексуальне життя нинішнього суспільства можуть призвести до підвищення рівня скоєння злочинів проти статевої свободи та статевої недоторканості. Майбутнім будь-якої держави є діти, і від того, як відбувається їх захист, залежить їхне життя в сучасному світі.

Аналіз останніх досліджень і публікацій. Історичний період існування людства характеризувався своїми особливостями щодо захисту неповнолітніх осіб. Для того щоб зрозуміти соціальне навантаження та захисний сенс цих кримінально-правових норм, потрібно проаналізувати детальніше історичний аспект виникнення цих заборон, які на той момент були спрямовані на захист статевої недоторканності неповнолітніх осіб. Історії сексуальних заборон було присвячено багато досліджень із боку фахівців із різних галузей науки. Вагомий внесок у вивчення цього питання зробили такі науковці, як: А.О. Джужа, Ю.М. Антонян, О.В. Синєокий, І.С. Кон, Є.О. Торчинов, Н.А. Ісаєв, А.М. Ходич, В.Г. Гітін, Ю.В. Александрова, О.М. Ігнатова, Л.І. Мороз та інші.

Мета статті - дослідити правові та релігійні пам’ятники того часу та виявити, які зміни відбувалися в законодавстві стосовно статевих злочинів із неповнолітніми протягом усього часу становлення та розвитку суспільства.

Виклад основного матеріалу дослідження. Якщо заглянути вглиб історії людства, то можна дізнатися те, з чого починався взагалі злочин. На той час відводилось не останнє місце сексуальному життю з боку законодавства, тобто існувало розуміння важливості цього питання для стабільності та розвитку суспільства. Потрібно детальніше проаналізувати історичний аспект щодо протидії цьому злочину й усвідомити соціальне навантаження та соціальний сенс щодо заборони розбещення неповнолітніх. Завдяки вивченню документів щодо історії людства, які дійшли до нас із того часу, можна стверджувати, що протягом різного часу існувала безліч заборон щодо статевих стосунків із дітьми. Історичний розвиток українського законодавства щодо статевих злочинів із неповнолітніми характеризується суперечливим ставленням самого суспільства та держави загалом. Це може

(ㄷ) О. Л. Іванова, 2021 
говорити про те, що тривалий час особи, з якими відбувався злочин, не досягли статевої зрілості та не були захищені кримінально-правовою нормою від насильницьких форм статевих зносин, які могли з ними відбуватися.

Ці питання можуть бути пов'язані з віковою межею легітимності статевих стосунків. Дослідження стародавніх правових пам'яток дає змогу зробити висновки про те, що людство на той час усвідомлювало неприпустимість скоєння статевих злочинів щодо неповнолітніх. Але щодо скоєння таких злочинів з особою, яка не досягла статевої зрілості, вважалось в деяких випадках як прояв блуду або перелюбством, якщо один із учасників цього злочину перебував у шлюбі. Існували норми відповідальності щодо здійснення з неповнолітніми статевого акту ненасильницького характеру, що на той час могло розглядатися як кровозмішення або блуд як із боку хлопця, так і з боку дівчини [1, с. 35].

На той час діти потребували спеціальної охорони та піклування через розумову та фізичну незрілість, цей захист був закріплений у законодавстві й починав діяти як до народження, так і після. Законодавство в сфері регулювання відповідальності за ненасильницькі посягання щодо статевої недоторканності неповнолітніх $€$ порівняно молодим. На початку існування Стародавнього Сходу та Міжріччя не існувало будь-яких історичних доказів стосовно юридичних заборон можливості вступу в статеві зносини з дітьми. Тому що та території цих регіонів існували та діяли закони, які в собі закріплювали норми, що могли забороняти перелюбство та згвалтування. На той час дитина не вважалася повноцінним учасником суспільних відносин, тому тривалий період часу діти розглядалися як власність батьків або опікунів, які могли керувати життям дитини та їі долею, і це говорить про те, що рішення батьків дорівнювалося закону.

Тому насильницьке діяння розглядалось як дія, яка може нести за собою образу за скоєння насильства і може тягнути за собою помсту з боку батьків. За такі злочини йшло дуже жорстоке покарання, тому насильницькі діяння стосовно неповнолітніх каралися смертю. Вже в той час в нормативно-правових актах можна було натрапити на такі поняття, як безчестя та блуд як противоправна форма сексуальної поведінки. Але самостійним складом злочину неможливо було назвати, тому що ці діяння розглядалися як можливість заподіяти майнову шкоду. У Стародавній Русі статеві злочини перебували в юрисдикції церкві, а відповідальність за такі злочини регулювалася переважно церковним законодавством. Тому на законодавчому рівні в церкві відбувалася охорона інституту шлюбу, який змінив саме ставлення до статевих злочинів [2, с. 141]. Тому можна зробити висновок, що в зазначений період на території Русі відповідальність за статеві злочини регулювалася державою та церквою. Першим правовим документом за часи Київської Русі була «Руська правда», і вже тоді в ньому містилась згадка про статеві злочини та відповідальність за такі злочини. Але на той час були відсутні точні ознаки щодо складу злочину та було незрозуміло саме формування та тлумачення злочину, це не надавало можливості скласти належного уявлення про рівень кримінально-правової регламентації за такі статеві злочини [3, с. 23]. У стародавніх літописах згадувалося, що викрадення нареченої, яка на момент шлюбу не досягла чотирнадцяти років, є поширенням сексуального насильства, яке виходило з дохристи- 
янських стародавніх шлюбних обрядів. Але такі стародавні шлюбні обряди на той час викликали між родами тільки ворожнечу, тому надалі такі обряди трансформувалися у викуп або відступні з боку родичів нареченої.

Тому в Статуті князя Ярослава Мудрого «Про церковні суди» говорилося про заборону батьками під страхом церковного покарання насильно видавати дівчину заміж або одружувати отрока. Покаранням за такі злочини була матеріальна відповідальність перед церквою [4, с. 89]. 3 поширенням на Русі християнства відбувається поділ влади на релігійну та світську, але ще відбувається співвідношення такого поняття, як гріх і злочин. Згідно з таким поділом вважалося, що всякий злочин - гріх, але не всякий гріх може бути злочином. Зазначалося, що «Положення про згвалтування» у самостійну норму виділялось не у всіх законодавчих актах того часу. Протягом кількох століть неповнолітні не були під особистим захистом суспільства та держави. Правління Петра I ознаменувалося формуванням нових культур і ламанням старих традицій, але й деяких змін із боку держави щодо статевих злочинів стосовно неповнолітніх. Стали мати місце нові кримінально-правові норми, що знайшли своє закріплення у Військовому артикулі, який ухвалили у 1715 році і в якому застосовувалися загальні правові норми щодо охорони статевої недоторканності неповнолітніх. Але згідно з цим Військовим артиклем неповнолітні не перебували під особистим захистом ані держави, ані суспільства, тобто статеві злочини прирівнювалися до статевих збочень. Тому дуже стисло було окреслено коло таких злочинів в окремих главах Артикля, які мали назву «Про содомський гріх», «Про насильство та блуд», у якому містилася низка норм, що передбачали відповідальність за різні форми сексуальної поведінки. У XIX ст. у російському та зарубіжному кримінальному праві важливою ознакою стало те, що згвалтування почали вважати насильницьким злочинам, який передбачає не тільки статеве насильство над особою, але й фізичне. Значною віхою в охороні інтересів сім'ї, дітей та моральності можна вважати «Уложення про покарання кримінальних та виправних» 1845 року, де було кодифіковано різні кримінально-правові акти, в яких було представлено систему норм, метою якої є кримінально-правова охорона статевої свободи та статевої недоторканності [5, с. 214]. Тому варто зауважити, що, незважаючи на досить докладну регламентацію щодо відповідальності за статеві злочини, вирізняються лояльністю та пом'якшенням покарання за такі злочини, тобто якщо відповідальністю за ці злочини була смертна кара, то потім її змінили на виправні роботи. Зокрема, у Кримінальному уложенні 1903 року коло статевих злочинів було розширено, їх поділяли на групи: по-перше, безпосередньо пов'язані із задоволенням сексуальних потреб; по-друге, непов'язані із задоволенням статевих потреб. Тому ці злочини були об'єднанні у 27 главах «Про розпусту» в Уложенні 1903 року, було дано вікові розмежування щодо потерпілих, з якими було скоєно статеві злочини, та було відокремлену групу жертв насильницьких злочинів. Отже, у кінці XVIII - на початку XIX ст. у кримінальному праві було сформовано, а в Уложенні 1903 року було законодавчо врегульовано об'єкти кримінально-правової охорони, які можуть стосуватися як статевої свободи, так і статевої недоторканності особи [6, с. 200]. 
Черговим етапом у розвитку вітчизняного законодавства в сфері захисту статевої недоторканності неповнолітніх є ухвалення першого Кримінального кодексу РСФСР 1922 року. З ухваленням нового Кримінального кодексу 1922 року поняття «зґвалтування» стало більш конкретним. 3'явилися обов'язкові ознаки складу злочину - як застосування фізичного, так і психологічного насильства, яке може використовуватися за безпорадного стану жертви злочину. У Кримінальному кодексі було передбачено розділ «Злочини в сфері статевих відносин», в якому було передбачено кримінальну відповідальність за статеві злочини, об'єктом яких є статева недоторканність неповнолітньої особи [7, с. 234]. На законодавчому рівні було використано нові терміни щодо визначення потерпілого як «особа, яка не досягла статевої зрілості». На той час статева зрілість потерпілої особи розглядалась не тільки як у біологічному (фізичному) сенсі, а як остаточне формування соціалізації особи в житті [8, с. 21]. Тому щоб залучити особу до кримінальної відповідальності, необхідно було встановити факт усвідомлення винної особи тієї обставини, що вона здійснила статевий злочин з особою, яка не досягла віку статевої зрілості. Кримінальний кодекс 1922 року передбачав більш небезпечний вид посягання - «статеві зносини з особами, які не досягли статевої зрілості, та поєднане з розтлінням чи задоволенням статевої пристрасті у збочених формах" [9, с. 30]. Наступним законодавчим актом, який регламентував відповідальність за статеві злочини, є Кримінальний кодекс 1926 року, з ухваленням цього кодексу було виділено у спеціальний розділ главу 6 «Злочини проти життя, здоров’я, волі, свободи і гідності особистості» відповідальність за такі злочини каралося позбавленням волі на строк до трьох років. Радянські законодавці того часу очевидно надто широко розуміли статеві злочини з особами, які на момент скоєння з ними злочину не досягли статевої зрілості. Та об`єднавши у цьому складі злочину різні за важкістю посягань на статеву недоторканість особи тобто: по перше добровільні статеві зносини з особою яка не досягла статевої зрілості, та по друге поєднання цих зносин з розтлінням та із задоволенням статевої пристрасті в збочених формах. Кримінальне право та дія Кримінального кодексу 1960 року того часу розглядала статеві злочини та посягання на статеву свободу і недоторканість неповнолітніх як порушення моральних і соціальних принципів щодо розвитку неповнолітніх у суспільстві [10, с. 210]. Згідно з Кримінальним кодексом 1960 року за вчинення розпусних дій з особою, яка не досягла статевої зрілості, було передбачено кримінальну відповідальність та покарання від трьох до шести років. Отже, КК УРСР містив цілком достатню кількість норм, які були спрямовані на захист інтересів неповнолітніх в сфері статевих посягань, що передбачають насильницькі злочини та ненасильницькі статеві злочини [11, с. 21]. Важливим етапом удосконалення та розвитку кримінального законодавства радянського часу стало ухвалення кодифікованих актів, Кримінальних кодексів 1922, 1926, 1960 років. Варто зазначити, що ухвалення нових законодавчих актів і вдосконалення кримінально-правових норм, які можуть стосуватися захисту неповнолітніх від сексуальних посягань, тривають і нині. Сучасний етап розвитку українського законодавства і суспільства характеризується суперечливими тенденціями, в якому Україна подолала наслідки системної політичної та соціальної-економічної кризи кінця XX ст. 
та було припинено падіння рівня якості життя. Із набуттям чинності 2001 року нового Кримінального кодексу України передбачалась відповідальність за розбещення неповнолітніх, було додано кваліфікуючі ознаки діяння, але законодавець не окреслив об'єктивної сторони цього питання. У Кримінальному кодексі України та в його особливій частині назріла потреба у відокремленні в самостійний розділ таких посягань, як «злочини проти статевої свободи та статевої недоторканності особи». Але якщо порівняти законодавство 1960 року та законодавство сьогодення, то можливо помітити певні зміни, тобто: по-перше, в усіх насильницьких злочинах законодавством було передбачено, що потерпілою особою може бути будь-хто, незалежно від віку та статі; по-друге, інакше визначався зміст самої погрози, а саме йшлося про погрозу тільки фізичного насильства, також відповідальність за посягання на статеву свободу та статеву недоторканність було доповнено низкою нових кваліфікаційних ознак [12, с. 20]. В Україні сьогодні немає будь-яких державних програм щодо формування статевої свідомості в сучасної молоді. Збільшення доступних різноманітних сексуальних відносин говорить про те, що не досить уваги приділяється з боку батьків і держави статевому вихованню, що приводить до зниження психосексуальної культури.

Висновки. Отже, підбиваючи підсумки, треба зазначити, що протидією розпусним діям сексуального характеру стосовно неповнолітніх дітей займалися ще в античному світі. Ці дії спочатку мали характер табу, які, відповідно, грунтувались на традиціях і моралі, згодом у нормативних актах вони отримали закріплення, яке регулювало суспільне життя в суспільстві. Суспільну небезпечність цього діяння було усвідомлено протягом історичного існування людством, що зумовило виведення злочинів стосовно неповнолітніх осіб в окремий склад злочину. Покарання за такі злочини змінювалося під впливом історичних обставин та особливостей національного менталітету щодо моральних релігійних і культурних цінностей. Сьогодні в більшості країн проводиться активна політика стосовно протидії сексуальному насильству щодо неповнолітніх. Тому чим цивілізованішим є суспільство, тим більше воно приділяє увагу розвитку та захисту психологічного здоров'я та моральних якостей неповнолітніх дітей. Тому український законодавець визнає необхідність щодо криміналізації розпусних дій сексуального характеру, які вчиняються з особами, що не досягли шістнадцятирічного віку, тобто він узяв на себе зобов'язання протидіяти цьому злочину та захищати нормальне фізичне та психологічне життя неповнолітньої особи в суспільстві.

\section{Jimepamypa}

1. Гусева О.Н. Педофильная виктимизация и виктимологическая профилактика педофильных преступлений : дис. ... канд. юрид. наук : 12.00.08 / Всероссийский научный исследовательский институт МВД. Москва, 2011. 245с.

2. Исаев Н.А. Сравнительно-исторический аспект половых преступлений. История развития уголовного права и ее значение для современности : материал V международ. наук.-прак. конф., м. Москва 26-27 мая 2005 г. Москва, 2006. С. 141-146.

3. Ивик О. И. История сексуальных запретов и преступлений. URL: http://www.e-reading.ws/ chapter.php/1010180/5/Ivik_-_Istoriya_seksualnuh_zapretov_i_predpisansy.html.

4. Плухарт А.П. Морали: Сочинение. навч. пособ. Харьков : Фолио, Харьков 1999. 120 с. 
5. Синєокий О.В. Психолого-правові проблеми кримінальної сексопатології. Вступ до криміноперверсології : монографія. Запоріжжя : ЗНУ, 2009. $360 \mathrm{c.}$

6. Чистяков О.И. Российское законодательство X-XX веков: учеб пособ Москва: 1984. 432 с.

7. Люблинский П.И. Преступления в области половых отношений: монография. Москва. $1925.249 \mathrm{c}$.

8. Гоноренко О.А. Пудовочкин Ю.Е. Защита несовершеннолетних от сексуального совращения и сексуальной эксплуатации: уголовно правовые проблемы. Учеб. пособ. Ставрополь. 2003. 45 с.

9. Дудоров О.О. Злочини проти статевої свободи та статевої недоторканості особи (основні положення кримінально-правової характеристики): практ. порад. Одеса: 2018. 92 с.

10. Чугуніков I.I. Система статевих злочинів за кримінальним законодавством України: проблеми вдосконалення. Сучасне право України: наукові нарими: монографія. Одеса: 2017. 400 с.

11. История развития законодательства об ответственности за половые преступления. URL: http: //www.studylaw.narod.ru $\backslash$ kursup3/kursup3_6_1.

12. Дьяченко А.П. Кримінально-правова охорона прав громадян в сфері сексуальних відносин: навч. посіб. Запоріжжя: 1995.100 с.

13. Холод О.П. Поняття, спільні ознаки та класифікація злочинів проти статевої свободи і статевої недоторканості особи: навч. посіб. Київ: 2015.135 с.

14. Рожко Т.А. Деякі питання кримінально-правової класифікації злочинів проти статевої свободи та статевої недоторканності : навч. посіб. Київ, 2016. 56 с.

\section{Анотація}

Іванова О. Л. Історичний аспект виникнення та розвитку відповідальності за статеві злочини щодо неповнолітніх осіб. - Стаття.

Статтю присвячено аналізу історичних тенденцій щодо розвитку вітчизняного законодавства та кримінальної відповідальності за статеві зносини з особами, які не досягли статевої зрілості. Розв'язання проблеми захисту неповнолітніх від сексуальних злочинів і посягання на їхню честь і гідність неможливе без звернення до історично-правових аспектів. Ретельне вивчення історії розвитку кримінальної відповідальності за статеві злочини проти неповнолітніх дає нам змогу виявити, який є рівень розвитку відповідальності, та зрозуміти, які існують перспективи щодо вдосконалення законодавства з цього питання. Історичний розвиток законодавства стосовно статевих злочинів може сягати в далеке минуле, коли відповідальність за такі злочини регулювалася переважно законами церкви. Тому будьяка держава, яка існувала або проходила стадію розвитку за той час, мала свої законодавчі акти, що регулювали ту чи іншу сферу життя суспільства. Закони з часом проходять багато стадій удосконалення, тому якщо сьогодні порівняти будь-який нормативно правовий акт сучасності, можливо знайти в ньому багато різних аспектів щодо захисту неповнолітніх від різних посягань на їхню честь і гідність. Історичний етап існування людства на той час характеризувався різними особливостями та мав багато заборон, які стосувалися злочинів щодо неповнолітніх. Тому врегулюванню сексуального життя суспільства відводилась не останнє місце з боку законодавців того часу. Правники розуміли важливість таких питань, як захист неповнолітніх осіб від посягання на їхню статеву свободу та статеву недоторканність, для розвитку надалі стабільного та сучасного суспільства. Діти є майбутнім будьякої держави, і від того, як відбувається їх захист на різних сферах їхнього життя, залежить розвиток сучасного законодавства. Тому історичний розвиток українського законодавства щодо злочинів, які було скоєно з неповнолітніми, має характерні суперечки щодо ставлення держави до відповідальності за такі злочини. Історичний аналіз норм стосовно статевих злочинів показав, що вітчизняне законодавство на різних етапах свого зародження виділяло такі злочини в окремий інститут.

Ключові слова: держава, неповнолітні, статеві злочини, відповідальність, захист, захист прав та інтересів. 


\section{Summary}

Ivanova $O$. L. Historical aspect of the origin and development of responsibility for sexual crimes against minors. - Article.

This article is devoted to the analysis of historical trends in the development of domestic legislation and criminal liability for sexual intercourse with persons who have not reached sexual maturity. The problem of protecting minors from sexual crimes and encroaching on their honor and dignity is not possible without recourse to historical and legal aspects. Careful study of the history of criminal liability for sexual crimes against minors allows us to identify the current level of development of liability and understand the prospects for improving the legislation on this issue. The historical development of legislation on sexual crimes may date back to the distant past, when liability for such crimes was governed mainly by the laws of the church. Therefore, any state that existed or underwent a stage of development and at that time, had its own legislation that regulated a particular area of society. Laws go through many stages of improvement over time, so if we compare any legal act of today, it is possible to find in it many different aspects of protecting minors from various encroachments and their honor and dignity. The historical stage of human existence at that time was characterized by various features, and had many prohibitions relating to crimes against minors. Therefore, the regulation of the sexual life of society was given not the last place by the legislators of that time. The lawyers understood the importance of such issues as the protection of minors from encroachment on their sexual freedom and sexual integrity for the further development of a stable and modern society. Children are the future of any state, and the development of modern legislation depends on how they are protected in various spheres of life. Therefore, the historical development of Ukrainian legislation on crimes committed with minors is characterized by controversy over the attitude of the state to responsibility for such crimes. Historical analysis of the norms concerning sexual crimes has shown that the domestic legislation at different stages of its origin allocated such crimes to a separate institution.

Key words: state, juveniles, sexual crimes, responsibility, protection, protection of rights and interests. 